\title{
TRANSBOUNDARY DISEASES AND WILDLIFE MANAGEMENT: AN OVERVIEW
}

\author{
O. O. Oludairo ${ }^{1 *}$, J. O. Aiyedun ${ }^{1}$, I. D. Olorunshola ${ }^{2}$, M. A. Dibal ${ }^{3}$, A. A. Gungbias ${ }^{3}$, A. M. J. Ayeni ${ }^{3}$ \\ and A. J. Adeyi ${ }^{4}$
}

${ }^{1}$ Department of Veterinary Public Health and Preventive Medicine, ${ }^{2}$ Department of Veterinary Microbiology, Faculty of Veterinary Medicine, University of Ilorin, Nigeria; ${ }^{3}$ National Museum Zoological Garden, Jos, Nigeria; ${ }^{4}$ Museums Department, Conservation Unit, National Commission for Museums and Monuments. Jos, Nigeria.

\begin{abstract}
Wildlife is the fauna and flora that are out of the control of man, although over the years common usage, public perceptions and history have practically defined wildlife as undomesticated free ranging terrestrial vertebrates which include reptiles, amphibians, birds, mammals excluding fishes. Wildlife play important roles in the epidemiology of emerging and re-emerging diseases either as vectors such as in rabies, primary target of disease such as in botulism and reservoirs such as in tularemia, Ebola virus disease (EVD), Severe Acute Respiratory Syndrome (SARS) and Middle East Respiratory Syndrome (MERS) . These diseases usually transcend national and regional borders causing high mortalities and morbidities. The transboundary nature of such epidemics and the collaborative efforts in combating the scourge was investigated using published literature. Wildlife has been incriminated in the occurrence and spread of various diseases many of which led to loss of lives and have the potentials of being pandemic. Diseases were promptly controlled in cases where collaborative efforts were applied in the management. Since the world is now a single global village, advanced collaborative strategic guidelines should be established for implementation and prevention of future pathogenic zoonosis within states, regions, continents and globally. Transboundary public health education of the citizenry will be of immense importance in the control and prevention of these diseases. Sustainable development goals (SDGS), poverty alleviation, enhanced culture and eco-tourism may not be realizable in the face of ignorance and disease. Highly pathogenic emerging and re-emerging zoonotic diseases and epidemics involving wildlife have grave consequences on national, regional, continental and world economies. These could however be prevented and controlled through multifaceted collaborative efforts and cooperation transcending geographical borders so that the planet can be rescued from the raging scourge of disease.
\end{abstract}

Key words: Wildlife, management, transboundary, diseases

\section{INTRODUCTION}

Wildlife diseases affect many other hosts. They impact on public health, national/regional economies, wildlife conservation and biodiversity (Daszack et al., 2000, Kruse et al., 2004). Reports suggest that 8 out of every 10 animal related pathogens in the United States of America have link with wildlife (Kruse et al., 2004). These numbers of identified infectious diseases are reported to be on the increase. They cut across tribe, languages, culture, boundaries, nations and regions posing potential threat to global health (Osofsky et al., 2003, Miller et al., 2013). The interaction of wildlife with other hosts, the increasing movement of human population, livestock, livestock products across countries and regions have led to the spread of pathogens across boundaries and consequent disease spread within human and animal population (Kock, 2005, Basagoudanavar and Hosamani, 2013).

It is widely accepted that the total eradication of shared infectious agents is almost impossible if wildlife hosts which serves as the natural reservoirs are ignored (Osofsky et al., 2003). A collaborative effort of multiple disciplines involving regional/continental and global countries required if the health of human beings, livestock, wildlife and the environment is to be improved and avoidable economic losses avoided (Daszack et al., 2007, FAO/OIE/WHO, 2008).

\section{TRANSBOUNDARY DISEASES}

Transboundary diseases are those that have very high probability of easily spreading across national, regional and international borders, they are often highly contagious in nature affecting domestic animals, wildlife and humans leading to enormous socioeconomic and public health challenge, significant economic, trade and/or food security issues (Kock, 2005). In affected areas control/management including exclusion, requires cooperation between several countries and regions (Basagoudanavar and Hosamani, 2013). This diseases are capable of causing population decline, adversely affecting food security, cripple national/regional economies and reduce trade relations (Otte et al., 2004).

*Corresponding e-mail address: oludairo@ hotmail.com 


\section{O.O. Oludairo and others}

\section{Food and Mouth Disease (FMD)}

It is a highly contagious disease that spreads among closed hoofed animal population infected through the current of the wind or by contact. This viral disease results in economic losses to food animals, farmers and countries dependent on export for foreign exchange. It is highly prevalent in large parts of the world especially in Sub Saharan Africa (Ellis and Putt, 1981, Bengis et al., 2002).

\section{Rinderpest}

This is also known as 'Cattle Plague'. It is the most devastating disease ever recorded. It spreads very fast among livestock infected herds on the move and through introduction of infected/carrier animals to uninfected herds and areas. Strict cattle movement controls, quarantine of infected areas, selective 'culling of infected herds and effective vaccination and vaccination campaigns especially through FAO coordinated programs like Global Rinderpest Eradication Program (GREP) have been effective against the plague (FAO/OIE, 2004, FAO, 2004, Rweyamann et al., 2006).

\section{Contagious Bovine Pleuropneumonia (CBPP)}

This is a gradual, harmful, low mortality or rapidly spreading high mortality disease of cattle in endemic and susceptible cattle populations respectively. The disease is spread majorly through movement of infected and carrier animals. It currently affects over 27 countries with an estimated annual cost of USD 2 Billion (Townseed and Sigwele, 1998).

\section{Bovine Spongiform Encephalopathy (BSE)}

This is a disease of cattle caused by 'Prions' occurring in many parts of the world. It is transmitted through feed supplements containing meat and bone meal infected with the organisms. Humans that consume infected beef can develop fatal neurological disease called variant Creutzfeldt-Jacob disease (FSA, 2002).

\section{Rift Valley Fever (RVF)}

This is a mosquito borne viral zoonosis, causing abortions and deaths in livestock and human populations. Infected mosquitoes often move with cattle populations during transit. Tens of thousands of morbidities and over a thousand human deaths have been recorded in Africa over a period of time (Okello et al., 2011).

\section{Peste Des Petits Ruminants (PPR)}

PPR is a debilitating contagious viral disease of sheep and goats. It spreads through contact with infected animals and material causing high mortality. Effective vaccination, disease surveillance and quarantine programs can help in the control of the disease (Kock, 2005, FAD PReP, 2014).

\section{African Swine Fever (ASF)}

This is the most fatal pig viral transboundary disease. It has the ability to spread over long distances through transportation of pork meat and its products including garbage containing pork food scraps. Wild pigs, warthogs and other wildlife serve as carriers and reservoirs and play important roles in the spread of the infection (FAO/OIE, 2004).

\section{Newcastle Disease (ND)}

This is a viral disease of poultry causing varying degree of morbidity and mortality. It is spread through bird to bird contact, contaminated food, water, utensils and other materials. Several wild birds serve as carriers and reservoirs of the disease. The disease is prevalent in Africa and Asia causing major economic losses in the poultry industry (Hafi et al., 1994, Domenech et al., 2006).

\section{Avian Influenza (AI)}

It is also referred to as 'fowl plague'. It is a highly fatal viral disease of poultry causing colossal loses in the poultry industry and with the ability to infect humans (FAO, 2008). It is spread through contact with infected birds and materials. The virus is reported to be widespread in wild water birds (FAD PReP, 2014, USDA APHIS AZA, 2016). 
Transboundary diseases and wildlife management

\section{Nipah Virus Disease}

This is a neutrotropic viral disease of livestock (especially swine) and human causing encephalitis and death. Fruit bats have been demonstrated to be natural reservoirs of the disease. In the outbreak that occurred in Malaysia in 1998/1999, the total cost of national economic damage was estimated at approximately USD541M (Cartin-Rojas, 2012).

\section{Ebola Virus Disease}

This affects both humans and non human primates causing haemorrhagic fever and death. Bats, pigs and non human primates have been identified as reservoir for the disease (Aiyedun and Oludairo, 2016, Fieldmann and Fieldmann, 2016). The total number of people with laboratory confirmed Ebola cases is 4655 with over 2431 reported cases of death (Palermo, 2014).

\section{Middle East Respiratory Syndrome (MERS)}

This is a rare, acute and sometimes fatal respiratory disease of humans and animals affecting mostly those who leave in or travel to the Arabian Peninsula (Mackay, 2015). Bats, camels and other animals have been identified as reservoir of this disease (Hemida et al., 2015, Kim et al., 2016). The virus is fatal in 20-40\% of those infected and has been reported in the Middle East, Europe, Asia, America and Africa (FAO, 2016).

\section{Severe Acute Respiratory Syndrome (SARS)}

This is a serious potentially life threatening viral respiratory infection of man and animal (Ong, 2016). Bats, masked civet cat and pigs have been identified as reservoirs of the virus (Shi and $\mathrm{Hu}, 2007$ ). The disease which was identified in Guangdong, China in 2002 and transmitted to Hong Kong and other countries recorded 5327 cases of infection and 774 deaths during the 2003 outbreak in China (Liu et al., 2014).

\section{Rabies}

This is a fatal global zoonotic disease of almost all mammalian species (Birhane et al., 2016). Humans, vampire bats, big brown bats, silver hair bats, raccoons, foxes, mongooses, dogs, cats, pigs, horses, cows, sheep and goats have all been reported to be reservoir hosts playing important roles in the ecology and epizootiology of the disease (Velasco-villa, 2013). The disease is responsible for more than 59,000 deaths annually with Africa (36.4\%) and Asia (59.6\%) recording the majority (Hampson et al., 2015).

\section{Botulism}

Is caused by the poisonous nerve toxin released by Clostridium botulinum (CDC, 2001). The disease manifests as muscle weakness and paralysis involving also the muscles of the respiratory tract (CDC\&P, 2016). Food and food products that harbor the bacteria and toxin usually move across borders (CDC\&P, 2016). This is the leading cause of death in aquatic birds in the United States (Newman et al., 2007).

The increase in the global occurrence of transboundary diseases is due to a number of intrinsic and extrinsic factors which include modernization, agricultural, ecological and climate change, increase movement of human population; livestock and livestock products; fish and fish products; plant and plant products, trade, global marketing, travel and traffic (FAO, 2008).

\section{ROLES OF WILDLIFE IN THE EPIDEMIOLOGY OF TRANSBOUNDARY DISEASES}

Environmental and socio-economical changes have led to an increase of interactions between wild and domestic species worldwide. It is now largely recognized that wildlife play important roles in the epidemiology of infectious diseases shared between wild and domestic species (Bengis and Kock, 2002). Pathogen maintenance within wildlife populations and spillover to livestock has been reported as a precursor to disease emergence in humans (Wolfe et al., 2007; Jones et al., 2008; Morse et al., 2012). Free range wildlife and those intended for the pet trade can serve as hosts for a variety of well-known and emerging zoonotic pathogens (Smith et al., 2005). The persistence of transmissible pathogens in wildlife and the possibility of their subsequent spread to domestic animals are put forward as a potential and sometimes major cause of the resurgence of infectious diseases of production animals and emerging/reemerging diseases in human (Kruse et al., 2004). 


\section{O. O. Oludairo and others}

\section{Wildlife as disease vector}

A vector is any agent, invertebrates or non-human vertebrates that transmits infective organisms into another or from one host to another (Roberts et al., 2008). For some diseases like rabies wildlife has began to replace domestic animals as the principal disease vector (Cathleen et al., 1999). Over 30 different types of diseases are associated with rats and their droppings (Hanlon et al., 1999).

\section{Wildlife as disease primary target}

Some diseases have specific wild animals as their primary target. Producing substances like toxins which cause disease conditions in other animals and man (Artois, 2012). This is the case in avian botulism where decomposing animal carcasses with toxin filled maggots are consumed by different species of birds and fish leading to their death (Reed and Roche, 1992).

\section{Wildlife as disease reservoir}

These are animate or inanimate objects which normally harbor disease-causing organisms and thus serve as potential sources of disease outbreaks. The reservoir typically harbors the infectious agent without injury to itself and serves as a source from which other individuals can be infected. The infectious agent primarily depends on the reservoir for its survival. It is from the reservoir that the infectious substance is transmitted to a human or another susceptible host (Siembieda et al., 2011).

The potential of wild animals as pathogen reservoirs and sources of infection for domestic livestock has been of increasing concern (Rhyan and Spraker, 2010). Wildlife species can be susceptible to many diseases that affect domestic livestock. For example, feral swine are susceptible to and can serve as a reservoir of classical swine fever and African swine fever viruses. Wild birds, particularly wild waterfowl, can serve as reservoirs for HPAI and virulent Newcastle disease (vNDV) (Siembieda et al., 2011). This susceptibility can contribute to the epidemiology of the outbreak as well as have implications on the international trade of domestic livestock or poultry (FAD PReP, 2014).

\section{WILDLIFE MANAGEMENT}

Despite the role played by wildlife in transboundary disease epidemiology, management efforts should be geared towards collaborative wildlife conservation and breaking disease cycles. This is because of the inestimable value of wildlife and the catastrophic effect other negative effort may have on the ecological balance of the earth (Osofsky et al., 2003, OIE, 2014). The management of wildlife species in the event of transboundary disease should involve steps aimed at effective disease control, containment and eradication (Wobeser, 2007, Delahay et al, 2009).

\section{Accessing extent of wildlife involvement}

There is need to access the epidemiological situation to determine the extent of risk of infection for the targeted pathogen by wildlife (Fischer and Gerhold, 2003, FAD PReP, 2014). The wildlife existing in the area will be accessed to determine whether they are infected or pose a risk for disease transmission. This involves consideration of the susceptibility of the wildlife present, their potential to spread disease and level of exposure and interaction between wildlife, domestic animals and humans (Meng et al., 2009, AUSVET PLAN, 2011).

If wildlife present is determined to be infected and pose a biological risk to livestock and man, wildlife management tools will be implemented to keep wildlife populations from acting as mechanical vectors (Siembieda et al., 2011). The wildlife population data could be obtained through population survey, ground surveys, aerial surveys, visual inspection and local reports or knowledge, wildlife carcasses, live animal capture and sentinel animals (AUSVET PLAN, 2011, USDA APHIS, 2014).

Disease surveillance in wildlife population

Based on wildlife population assessment, disease surveillance could be done. It could be based on visual surveillance and/or diagnostic testing (Wobeser, 2007). This will help to demonstrate the absence, presence, spread and or prevalence of disease in wildlife population (USDA, 2014). Diagnostic testing samples can be obtained from wildlife through live capture, observation and carcass collection which will be forwarded to diagnostic laboratories. These are usually handled by trained personnel who should observe appropriate biosecurity measures (OIE, 2010). 


\section{Infected wild animal containment and control}

The primary objective of containment and control is to stop the transmission of transboundary disease which can be a difficult task (Delahay et al., 2009, FAD PReP, 2014). Measures that could be employed to achieve this include manipulating wildlife populations to minimize disease spread, such infected wildlife may be removed, relocated or dispersed, vaccination/treatment of wildlife could also be done depending on the disease agent (OIE, 2010). Additional monitoring/surveillance, short/long term consequences and assessment of the impact on animal species and ecosystem should be well considered (USDA, 2014, USDA APHIS AZA, 2014). Manipulating wildlife habitat is another management option for containment and control. Physical structures like fences, habitant alterations like creating buffer zones between infected and uninfected wildlife, could be employed to change the distribution, density and population of wildlife populations (Wobeser, 2007). Another strategy that could be used is public (hunters, farmers, ranchers and others closely involved with wildlife) education and training for behavioral change so as to influence the spread of diseases through modification of hunting practices, alteration in the feeding of wildlife, baiting of wildlife and their consumption. They can also be trained on rapid identification of sick or atypical behavior of wild animals (Fischer and Gerhold, 2003).

\section{Demonstration of disease free wildlife}

To re establish public confidence and enhance international trade, there may be need to demonstrate disease freedom in wildlife. This require the implementation of wildlife disease surveillance plan for disease freedom based on the wildlife species involved, disease agent epidemiology and diagnostic tests (USDA APHIS, 2014).

\section{CONCLUSION}

Wildlife has been fingered in the epidemiology of many transboundary diseases. Most of these cases have heavy burdens on socio economic value of areas involved. This transcends national and regional boundaries leading to loss of life and economic drain (Otte et al., 2004). Control and prevention of these diseases in wildlife through well planned and properly thought out management plans could stem the spread of the diseases (USDA APHIS, 2016, Hampson et al., 2015). Due to the transboundary nature of the diseases however, collaborative efforts must be employed to effectively control these diseases across regions and continents. The effect of the collaborative effort is evident in effective control of Ebola virus disease in the West African sub region and the world at large in recent past (Palermo, 2014). Collaborative wildlife management will enhance the achievement of sustainable development goals (SDGS), reduce poverty and promote regional/continental tourism (Daszack et al., 2007, Liu et al., 2014).

\section{REFERENCES}

1. Aiyedun JO and Oludairo OO (2016). Epidemiological notes on Ebola Virus Disease in Nigeria. Assiut Veterinary Medical Journal 62: 168-171.

2. Artois M (2012). The role of wildlife in the control of domestic animal diseases. Conf OIE. Available @ www.oie.int. Accessed on $8^{\text {th }}$ September, 2016.

3. AVSVET PLAN (2011): Operational Procedures Manual Wild Animal Response Strategy (2011). Available @ www.animalhealthaustralia.com.au. Accessed on the $9^{\text {th }}$ September, 2016.

4. Basagoudanavar SH and Hosamani M (2013). Transboundary diseases of animals: Mounting concerns. Vetscan 7: 119. Available on line@www.vetscan.co.in.

5. Bengis R, Kock R and Fischer J (2002). Infectious Animal Disease: the Wildlife/Livestock Interface. Scientific and Technical Review of the Office International des Epizooties 21: 53-65.

6. Birhane MG, Miranda MEG, Dyer JL, Blanton JD and Recuenco S (2016). Willingness to Pay for Dog Rabies Vaccine and Registration in Ilocos Norte, Philippines (2012). PLoS Neglected Tropical Diseases 10: n e0004486. doi:10.1371/journal.pntd.0004486

7. Cartin-Rojas A (2012). Transboundary animal diseases and international trade. Intech Open Journal 143-166. Chapter in International trade from economic and policy perspective.

8. Cathleen AH, Childs JE and Nettles VF (1999). Rabies in wildlife. Journal of the American Veterinary Medical Association 215: 1612-1619.

9. CDC\&P (2016). Communicable Disease Control and Prevention. San Francisco Dept of Public Health. Botulism. Available@www.sfedp.org/botulism. Accessed on 6 ${ }^{\text {th }}$ September, 2016. 


\section{O. O. Oludairo and others}

10. CDC (2001). Centre for Disease Control. Emergency Preparedness and Response: Facts about Botulism. Availble@www.emergency.cdc.gov/agent/botulism. Accessed on $8^{\text {th }}$ September, 2016.

11. Daszack P, Epstein J, Kilpatrick A, Aguirre A, Karesh,W, Cunningham A (2007). Collaborative Research Approaches to the Role of Wildlife in Zoonotic Diseases Emergence. Current topics in Microbiology and Immunology 315: 463-475.

12. Daszak P, Cunningham AA, Hyatt AD. (2000). Emerging infectious diseases of wildlife - threats to biodiversity and human health. Science 28: 443-9. doi: 10.1126/science.287.5452.443

13. Delahay RJ, Smith GC, Hutchings MR, eds. (2009). Management of disease in wild mammals. Springer: Tokyo.

14. Domenech J, Lubroth J, Eddi C, Martin V, Roger F (2006). Regional and international approaches on prevention and control of animal trans-boundary and emerging diseases. Annals of the New York Academy of Science 1081: 90107.

15. Ellis PR and Putt SN (1981). The epidemiological and economic importance of Foot and mouth disease in Kenya.

16. FAD PReP (2014). Foreign Animal Disease Preparedness and Report Plan. NAHEMS GUIDELINES: Wildlife management and vector control for a foreign animal disease response in domestic livestock. Available@www.aphis.usda.gov Accessed on $8^{\text {th }}$ September, 2016.

17. FAO (2004). Food and Agriculture Organization of the United Nations and World Organization for Animal Health the Global Framework for the Progressive Control of Transboundary Animal Diseases (GF-TADs). Rome: FAO. pp. 40.

18. FAO (2008). Expert meeting on climate related trans-boundary pests and diseases including relevant aquatic species. FAO headquarters, 25-27 February 2008. Rome, Italy.

19. FAO (2016). MERS-Cov situation update. FAO emergency prevention system for animal health (EMPRES-AH). Available@www.fao.org/ag/againinfo. Accessed on 6th September, 2016.

20. FAO/OIE (2004). Food and Agriculture Organization of the United Nations and World Organization for Animal Health. The Global Framework for the Progressive Control of Transboundary Animal Diseases (GF-TADs). Rome: FAO. $40 \mathrm{p}$.

21. FAO/OIE (2004). Joint FAO/OIE initiative. The global framework for the progressive control of trans-boundary animal diseases (GF-TADs).

22. FAO/OIE/WHO/UNSIC/UNICEF (2008). World Bank. Contributing to One World, One Health: A Strategic Framework for Reducing Risk of Infectious Diseases at the Animal-Human-Ecosystem Interface. (2008). Available from: http://un-influenza.org/sites/default/files/OWOH_14Oct08.pdf

23. Fieldmann F and Fieldmann H (2016). Ebola: Facing new transboundary disease? Journal of Developmental Biology 135: 201-209.

24. Fischer JR and Gerhold RW (2003). The role of wildlife in human and animal disease. Proceedings of the 10th Wildlife Damage Management Conference. (April 6-9, 2003, Hot Springs, Arkansas), pp.265-274.

25. FSA (2002). Food Safety Agency, UK Review of BSE control, final report.

26. Hafi A, Reynolds R and Oliver M (1994). Economic impact of Newcastle Disease on the Australian poultry industry, Canberra. Australian Bureau of Agricultural and Resources Economics pp. 77.

27. Hampson K, Coudeville L, Lembo T, Sambo M, Kieffer A and Attlan M (2015). Estimating the global burden of endemic canine rabies. PLoS Neglected Tropical Diseases 9: e0003709. Epub 2015/04/17. doi: 10.1371/journal.pntd.0003709 pmid:25881058.

28. Hanlon CA, Childs JE and Nettles VF (1999). The National Working Group on Rabies Prevention and Control. Journal of the American Veterinary Medical Association 215: 1612-1618.

29. Hemida MG, Elmoslemany E, Al-Hizab F, Alnaeem A, Almathen F, Faye B, Chu DKW, Perera RAPM and Peiris M (2015). Dromedary camels and the transmission of Middle East Respiratory Syndrome Corona virus (MERSCoV). Transboundary and Emerging Diseases. doi: 10.1111/tbed.12401.

30. Jones KE, Patel NG, Levy MA, Storeygard A and Balk D (2008) Global trends in emerging infectious diseases. Nature 451: 990-993.

31. Kim HK, Yoon SW, Kim DJ, Koo BS, Noh JY, Kim JH, Choi YG, Na W, Chang KT, Song D and Jeong DG (2016). Detection of Severe Acute Respiratory Syndrome-Like, Middle East Respiratory Syndrome-Like Bat Corona viruses and Group H Rotavirus in faeces of Korean Bats. Transboundary Emerging Diseases 63: $365-372$. doi:10.1111/tbed.12515. 
32. Kock R (2005) What is this infamous "wildlife/livestock disease interface?" A review of current knowledge for the African continent. Conservation and Development Interventions at the Wildlife/Livestock Interface. Implications for Wildlife, Livestock, and Human Health, ed Osofsky SA (International Union for Conservation of Nature, Cambridge, UK).

33. Kruse H, Kirkemo A and Handeland K (2004). Wildlife as Source of Zoonotic Infections. Emerging Infectious Diseases 10: 2067-2072.

34. Liu Q, Cao L and Zhu X (2014). Major emerging and reemerging zoonosis in China: a matter of social health and socioeconomic development for 1.3 Billion. International Journal of Infectious Diseases 25: 65-72.

35. Mackay IM. (2015). Middle East Respiratory Syndrome (MERS): Aprimer. Infection control tips. Available $@$ www.infectioncontrol.tips/2015. Accessed on $6^{\text {th }}$ September, 2016.

36. Meng XJ, Lindsay DS, Sriranganathan N (2009). Wild boars as sources for infectious diseases in livestock and humans. Philosophical Transactions of the Royal Society B: Biological Sciences 364: 2697-2707.

37. Miller RS, Farnsworth M and Malmberg JL (2013). Diseases at the livestock-wildlife interface: status, challenges, and opportunities in the United States. Preventive Veterinary Medicine 110: 119-32. doi:10.1016/j.prevetmed.2012.11.021

38. Morse SS, Mazet JA, Woolhouse M, Parrish CR, Carroll D, Karesh WB, Zambrana-Torrelio C, Lipkin WI, Daszak P (2012). Prediction and prevention of the next pandemic zoonosis. Lancet 380: 1956-1965.

39. Newman SH, Chmura A, Converse K, Kilpatrick AM, Patel N, Lammers E and Daszak P (2007). Aquatic bird disease and mortality as an indicator of changing ecosystem health. Marine Ecology Progress Series 352: 299-309.

40. OIE (2010). World Organization for Animal Health. Training Manual on Wildlife Diseases and Surveillance. Available @ http://www.oie.int/fileadmin/Home/eng/Internationa_Standard_Setting/docs/pdf/WGWildlife/A_

41. OIE (2014). World Organization for Animal Health. Terrestrial Animal Health Code. http://oie.int.

42. Okello A, Paul E, Gibbs J, Vandersmissen A and Welburn S (2011). One Health and the Neglected Zoonoses: Turning Rhetoric into Reality. Veterinary Record 169: 281-285.

43. Ong F (2016). Severe Respiratory Syndrome (SARS). Medscape. Available@www.emedicine.com/article/237755. Accessed on 6th September, 2016.

44. Osofsky S, Cleaveland S, Karesh W, Kock M, Nyhus P, Star L and Yang A (2003). Conservation and Development Interventions at the Wildlife/Livestock Interface. Implications for Wildlife, Livestock and Human Cambridge: IUCN Publications Services Unit. 241 p.

45. Otte MJ, Nugent R and McLeod A (2004). Trans-boundary animal diseases: Assessment of socio-economic impacts and institutional responses. Livestock policy discussion paper No. 9. FAO, Rome, Italy.

46. Palermo E (2014). Ebola mortality: Would outbreaks be as deadly in US as in Africa? Livw science. Available@ www.livescience.com. Accessed on $6^{\text {th }}$ September, 2016.

47. Reed TM and Rocke TE (1992). The role of avian carcasses in botulism epizootics. The Wildlife Society Bulletin vol. 20, p. 175-182.

48. Rhyan JC and Spraker TR (2010). Emergence of diseases from wildlife reservoirs. Veterinary Pathology 47: 34-39.

49. Roberts LS, John J, Gerald DS (2008). Foundations of Parasitology. McGraw Hill. ISBN 978-0-07-3028279. OCLC 226356765.

50. Rweyemamu MM, Musiime J, Thomson G, Pfeiffer D and Peeler E (2006). Future control strategies for infectious animal diseases- Case study of the UK and sub-Saharan Africa. In: UK Government's foresight project, infectious diseases: preparing for the future, pp. 1-24.

51. Shi Z and $\mathrm{Hu} \mathrm{Z}$ (2007). A review of studies on anal reservoirs of the SARS corona virus. Virus Research 133: 7484.

52. Siembieda JL, Kock RA, McCracken TA and Newman SH (2011). The role of wildlife in transboundary animal diseases. Animal Health Research Review 12: 95-111.

53. Smith KF, Dobson AP, McKenzie FE, Real LA, Smith DL and Wilson ML (2005). Ecological theory to enhance infectious disease control and public health policy. Frontiers in Ecology 3: 29-37.

54. Townseed RF and Sigwele HK (1998). Socioeconomic cost benefit analysis of action and alternatives for the control of contagious bovine plueropnuemonia in Ngamiland, Botswana. Final report, DFID, London.

55. USDA APHIS AZA (2016). Management Guidelines for Avian Influenza Zoological Parks Exhibitors Surveillance Plan. http://www.zooanimalhealthnetwork.org/ai/Home.aspx. Accessed 14th September, 2016.

56. USDA APHIS (2016). National Wildlife Disease Surveillance and Emergency Response System (SERS). Available at: http://www.aphis.usda.gov/wildlife_damage/nwdp/ER.shtml. 


\section{O. O. Oludairo and others}

57. USDA APHIS (2014). VS Guidance 12001: Procedures for the Investigation of Potential Foreign Animal Disease/Emerging Disease Incidents (FAD/EDI). Available at http://www.aphis.usda.gov/ animal_health/ lab_info_services/downloads/VSG_12001.pdf. Accessed 9th September, 2016.

58. USDA (2014). National Wildlife Disease Surveillance and Emergency Response System (SERS). Available at: http://www.aphis.usda.gov/wildlife_damage/nwdp/ER.shtml. Accessed 9th September, 2016.

59. Velasco-villa A (2013). Characterization of risk areas and species involved in transmission. National Center for Emerging and Infectious Diseases; Division of High consequence Pathogens and Pathology. Available www.paho.org/panaftosa/index.php?option=com_docman\&task=doc_download\&gid=418\&Itemid=156. Accessed on $6^{\text {th }}$ September, 2016.

60. Wobeser G (2007). Disease in wild animals, investigation and management. Heideiberg, Germany: Springer.

61. Wolfe ND, Dunavan CP and Diamond J (2007). Origins of major human infectious diseases. Nature 447: $279-283$. 